\title{
COSA MENTALE: EL PASADO COMO ARTIFICIO
}

\author{
Pilar García \\ Universidad de Chile, CONICYT \\ pilargarcia.pg@gmail.com
}

RESUMEN / ABSTRACT

El artículo propone una lectura de la novela de Antonio Gil, Cosa mentale (1994), como construcción artificiosa del pasado a través de la puesta en juego de los procedimientos pictóricos aplicados a la poesía. El dictum horaciano ut pictura poiesis será revisado a partir del registro delirante y experimental de una novela que indaga en las maneras de configurar el pasado histórico recurriendo a temporalidades alternativas al tiempo de la modernidad histórica. De esta manera, según un criterio analógico, es posible identificar retóricas de la imagen y de la representación a nivel narrativo, en correspondencia con la narratividad pictórica. Finalmente, se entrega una interpretación sobre la perspectiva transhistórica del narrador que permitiría entender las anacronías narrativas como rupturas entre tiempo de la modernidad y tiempo del mito.

Palabras Clave: ut pictura poiesis, Antonio Gil, artificio, Mulato Gil de Castro, novela histórica.

This article proposes a reading of the Antonio Gil's novel, Cosamentale (1994), as an artificial construction of the past through the pictorial procedures applied to poetry. Horatio's dictum ut pictura poiesis will be revised on the basis of this delirious and experimental novel that explores a ways to configure the historic past resorting to alternatives temporalities in respect of historical modernity time. In this way, according to an analogical criterion, we identified rhetorics of the image and the representation in the narrative level, in correspondence with the pictorial narrative. Finally, we give an interpretation about the transhistoric perspective of the narrator that explains narrative anachronisms between the time of modernity and the time of the myth.

KEY WORDS: ut pictura poiesis, Antonio Gil, artifice, Mulato Gil de Castro, historic novel. 
"También se ha entrado en la pintura el vocerío de la calle. Las pendencias de los escolares, el regateo, el maullido de los gatos en los tejados. Claro que eso ocurre porque Gil de Castro sólo es un pintor menor"

(Cosa mentale 93).

La aparición de Cosa mentale en 1994 dentro del panorama de la Nueva Narrativa, de alguna manera encauza las expectativas generadas por Hijo de mí (1992), primera novela de Antonio Gil. Su propuesta experimental, sumada a una continuidad temática, anuncia un proyecto de escritura: si en el caso de Hijo de mí la narración surge a partir de las relaciones entre memoria e historia, esta vez -según palabras del autor-se trata de la pseudobiografía de un personaje histórico: el mulato José Gil de Castro, "Capitán de Ejército, pintor de Cámara del Gobierno del Perú, segundo cosmógrafo, miembro de la mesa Topográphica y Antographista del Supremo Director" (Gil, Cosa mentale 6) es la figura elegida para revisar y recrear parte de la historia de Chile en el periodo de transición entre la Colonia y la Independencia.

La crítica periodística trató a la novela de manera favorable y, aparte de insistir en que la historia se presenta como un mero pretexto para la escritura -acompañada de declaraciones del autor del tipo "a mí la historia no me interesa en absoluto; me interesa el pasado, que es distinto" (Guerrero 3)-, advierte que no correspondería a una novela de personaje, aunque su protagonista sea el pintor José Gil de Castro, sino de época, biografía saboteada por la atmósfera de un periodo borrascoso y fantasmal: el paso del siglo XVIII al XIX. Con todo, Cosa mentale difícilmente puede leerse como una novela histórica tradicional e incluso como una nueva novela histórica ${ }^{1}$, ya que más bien responde a lo que Linda Hutcheon en Poéticas del postmodernismo denominó

Si bien la novela presenta algunas características del subgénero entregadas por Menton (La nueva novela histórica 1992), se distancia de las poéticas del boom que están en la definición de la nueva novela histórica (Rama 1980, Menton 1992). El diálogo de Gil con Carpentier es innegable -por ejemplo, en la trasposición de la pintura a la narración como ocurre en El siglo de las luces (1962) con el cuadro "Explosión en la catedral"-, pero no es el único ni el determinante al interior de su poética, mucho más relacionada con las fracturas utópicas de los relatos y los desarrollos locales de las formas narrativas que con el tratamiento neobarroco de la forma y el establecimiento de "alegorías barrocas" en el sentido de Carpentier. 
metaficción historiográfica ${ }^{2}$. La presencia conflictiva de los sustratos míticos de una cultura, la contienda por configurar y narrar una memoria histórica, así como la función significante y determinante de los materiales poéticos, son problemáticas recurrentes en el proyecto narrativo de $\mathrm{Gil}^{3}$.

\section{IMAGEN DEL PASADO: ENTRE LA HISTORIA DE LA NACIÓN Y LA HISTORIA DEL ARTE}

La situación de enunciación de la novela implica una ruptura en la jerarquía de los modos de acercamiento al pasado histórico en la medida en que ya no es el documento historiográfico la fuente primordial de su conocimiento ${ }^{4}$ : la introyección del pasado histórico ocurre a través de la percepción sensorial de una pintura -ya que el narrador encuentra en los óleos de Gil de Castro su principal documento, fuente o archivo-, pintura convertida en mónada, fragmento significativo, portador de la fuerza de dicho pasado. De tal manera, los archivos o las crónicas resultan materiales insuficientes para captar las dimensiones vitales y estéticas de un pasado relatado por medio de la sinestesia sometida al intelecto.

Recientes discusiones en torno a las lógicas narrativas de la historiografía (Didi-Huberman 46) han puesto de relieve el desafío y las implicancias de detenerse en las anacronías que el discurso positivista de la disciplina histórica ha constantemente rehuido, anacronías propias del material "bruto"

\footnotetext{
Dentro de sus ideas centrales, la autora señala: "In both fiction and history writing today, our confidence in empiricist and positivist epistemologies has been shaken -shaken, but perhaps not yet destroyed. And this is what accounts for the skepticism rather than any real denunciation; it also accounts for the defining paradoxes of postmodern discourses. [...] Historiographic metafiction [...] keeps distinct its formal auto-representation and its historical context, and in so doing problematizes the very possibility of historical knowledge, because there is no reconciliation, no dialectic here -just unresolved contradiction" (106).

A las obras mencionadas se suman las siguientes: Mezquina memoria (Cuarto Propio, 1997); Las playas del otro mundo (Seix Barral, 2004); Cielo de serpientes (Seix Barral, 2008); Tres pasos en la oscuridad (Sangría, 2009); Carne y jacintos (Sangría, 2010); Retrato del diablo (Sangría, 2012).

$4 \quad$ Este problema es el punto de partida para discutir profundas transformaciones y variantes en el género novela histórica, no solo a partir del boom o la nueva novela histórica, sino también en los regionalismos (Rama 1984) o en períodos historicistas. Por ejemplo, el caso de La gloria de Don Ramiro y su recurrencia a los códigos de la belle époque para dar cuenta del pasado y de la historia.
} 
de la historia, y propias también del relato ficcional. Pero ¿cuál es ese material histórico, mediatizado por la narración? ¿Lo es el tiempo, como categoría ontológica? ¿O los documentos? Y por consiguiente, ¿cuál es la temporalidad -propia o conferida- de dichos documentos? El problema del estilo en cuanto caracterización de una época, así como la definición de la contemporaneidad a partir de la legitimación de un estilo, para Didi-Huberman constituyen brechas, fisuras atendibles que permiten reconstruir sentidos históricos obliterados o neutralizados por narrativas históricas totalizantes. Dicha reconstrucción tendrá lugar precisamente al alero de las nociones de "estilo" y "contemporaneidad", inscritas en obras de arte que puedan cumplir una función tanto documental como monumental (también Le Goff 1991, 2005). El autor entrega un punto de partida: estar ante la imagen es estar ante el tiempo, enfrentado, más que a un pasado, al presente que "no cesa jamás de reconfigurarse" para reconocer que "probablemente ella nos sobrevivirá [...] La imagen a menudo tiene más de memoria y más de porvenir que el ser que la mira" $(12)^{5}$.

La contemplación de la imagen - de la pintura- se constituye en una poética dentro de la novela: los procedimientos narrativos constantemente implican o indican un acto de mirada, de distancia y de copresencia, cuyo resultado es una movilidad en las jerarquías generadas por el relato. De tal manera, los acontecimientos históricos, los hechos, en Cosa mentale devienen elementos secundarios, medios de que dispone el narrador (y no fines) para la trasposición lingüística (escritural) de aquello que expresan y representan las pinturas como actores y testigos de dicho pasado. La forma de escribir la novela, el modo de componerla, serían entregados -dictadospor la pintura y las leyes que esconde. En este contexto, la novela cumple el papel de artificio, no solo en cuanto código sustitutivo de la pintura, sino en cuanto se impregna de los conflictos estéticos y políticos de la representación como contexto artístico de las telas en un período que, en Latinoamérica, presenta las características del palimpsesto: una concepción manierista del arte, que aún utiliza recursos del Renacimiento, junto a un desarrollo inédito del Barroco, principalmente a cargo de la pintura religiosa indígena, sumado al ingreso del Rococó y Neoclasicismo que en el continente se instala desde

Esta posición teórica constituye un punto de partida radical para abordar el problema de las historicidades implicadas en los relatos de la historia y en el discurso de la historiografía, en particular, de la historia del arte, dejando abierta la pregunta en torno a los criterios para una historia de las imágenes (Didi-Huberman 2006). 
fines del siglo XVIII y alcanza plenitud en la primera mitad del siglo XIX, precisamente en función del surgimiento y establecimiento de una nueva clase social (burguesía criolla independiente) ${ }^{6}$. La pintura del Mulato Gil surge en medio de cruces y líneas paralelas de la pintura latinoamericana en que el retrato adquiere una finalidad política y social, pero cuyos fondos siguen remitiendo a otras tradiciones pictóricas que Cosa mentale, en su factura, reproduce.

La novela, en un gesto alegórico, hace dialogar las nociones postmodernas del arte-que ponen en evidencia el constructo y superponen o correlacionan eclécticamente los tiempos sin el imperativo de una cronología o una continuidad de estilo ${ }^{7}-$, con una perspectiva deliberadamente pasatista o decadente cuyo énfasis radica en que el trabajo consciente de los materiales, los procedimientos del arte y sus técnicas, así como la idea de que el acto de configuración de la obra es tanto o más significativo que los contenidos alojados en ella, son criterios que poseen una larga tradición en la historia del arte, identificados, paradigmáticamente, con el estilo manierista en la pintura. Junto a esto, la célebre y enigmática frase de Leonardo, "la pittura è una cosa mentale" que da título a la novela, sugiere coordenadas de lectura más amplias al aludir a las poéticas del Renacimiento.

En este sentido las pinturas del Mulato José Gil mostrarían al narrador los conflictos de una época atravesada por diversas concepciones de mundo no necesariamente ajustables a la ordenación periódica y dialéctica tanto de la historiografía nacional como de la historia del arte (tradición, influencias, despliegue, ruptura, sustitución), siendo este uno de los principales conflictos y encrucijadas desplegados en la novela. Como consecuencia, el criterio ut pictura poiesis, al comprometer variadas técnicas y procedimientos en la trasposición de los códigos y recursos de la pintura a los códigos de la poesía -como el de la narración pictórica-, es adoptado por el narrador como modo plausible y efectivo para dar curso al relato, ya que permite plantear que la realidad es un constructo -ideológico, si se quiere- y que el artificio es condición tanto para la representación del mundo como para su aprehensión. Las retóricas de la imagen identificadas en la composición

\footnotetext{
Para una mirada acerca del periodo de transición entre el siglo XVIII y XIX en la pintura latinoamericana (ver Álvarez de Araya 137-153).

Ver al respecto Huyssen, Andreas. "Guía del posmodernismo”. En: Casullo, N. El debate modernidad posmodernidad. Buenos Aires: Retórica, 2004, 229-267.
} 
de la novela, desarrolladas en los capítulos siguientes, se relacionan con diversas técnicas de la pintura y de la representación que la historia del arte ha vinculado según una periodización i) con el Renacimiento en las técnicas de la veladura, el esfumado, el claroscuro; ii) con el Manierismo en la apertura de perspectivas, la instalación de espacios abiertos, la representación antiheroica del héroe, la presencia del artista en la representación; y iii) con el Barroco en la perspectiva cinematográfica, lo inacabable de la obra, las escenas que parecen espiadas, etc. Estos procedimientos aparecen aplicados y replicados en la novela, sin el afán de constituir un modelo de estilos diferenciados, más bien lo hacen de manera aleatoria y superpuesta, mediados por la voz en abismo del narrador, cuya ubicuidad temporal le otorga el estatus de sujeto transhistórico, que habita el pasado con la carga del presente desde el cual sueña, lee o contempla el pasado, esto es, lo imagina y lo compone por medio de la novela, entendida como un marco de verosimilitud ${ }^{8}$.

No obstante, el artificio no es la condición última del mundo representado. El Mulato José Gil de Castro, como figura incidental o secundaria dentro de la historia nacional, delegado de un orden a través de las funciones que desempeña -cartógrafo, militar y retratista de los próceres de la patria-, refracta el marco histórico dejando ver un sustrato mítico que reordena no sólo los criterios historiográficos - de la historia de la nación, de la historia del arte-, sino los fácticos y representacionales, dislocando los imperativos de orden y verdad del mundo narrado.

\section{LA PINTURA Y LA POESÍA}

" "Siempre existió para los pintores y los poetas la justa libertad de atreverse a cualquier cosa'; lo sabemos, y pedimos y a la vez otorgamos esta facultad. Pero no de manera que lo verde se una a lo maduro, o las serpientes se apareen con las aves, o los corderos con los tigres" (Horacio, Arte Poética 265)

\footnotetext{
8 La voz del narrador es la responsable de la dimensión metadiscursiva de la novela, siempre consciente y atenta a lo que está narrando, correspondiendo a un caso especial de metalepsis, en la medida en que es constante. Es una voz que exhibe el desfase entre lo que ve y lo que narra: se detiene en el cómo de la narración, al mismo tiempo que lo somete a una constante revisión y desajuste. Esta fuerte carga reflexiva, presente desde el primer capítulo para luego dar paso a la narración-descripción del mundo, es el marco que el propio poeta/ narrador fija para "componer" la novela y observar el mundo.
} 
El procedimiento estético de la mimesis, desde Aristóteles, se aplica, fundamentalmente, a dos artes: la pintura y la creación literaria. Asimismo, el concepto antiguo ut pictura poiesis puede equipararse al de mimesis. Existiría, entonces, desde antiguo, una analogía entre pintura y poesía en relación con la manera visual -intelectiva e imaginaria- de aprehender el mundo9.

"La poesía es como la pintura. Habrá la que te atraerá más si estás más cerca y la que lo hará si estás más lejos. Esta requiere ser contemplada en la penumbra. Aquélla, que no teme la aguda sutileza del crítico, a plena luz. Esta, gusta una sola vez. Aquélla, repetidas veces, seguirá gustando" (Horacio. Arte poética 280).

Este modo de concebir la representación organizó el sistema de las artes hasta el siglo XVIII, periodo en que aparecen textos que reclaman la especificidad de los lenguajes y, por tanto, una separación entre las artes ${ }^{10}$. La famosa analogía fue retomada por el realismo literario decimonónico, que se proponía, a través de la narración, "pintar una época"; hacer tal y como el pintor, quien registra con formas y colores fielmente el "cuadro" de la sociedad. Balzac fue el promotor más entusiasta de esta idea que convertía al milieu en el friso realista. Sin ir más lejos, se trata de una analogía que ha tenido importantes desarrollos a lo largo del siglo $\mathrm{XX}^{11}$.

9 La primera referencia a esta analogía se encuentra en la afirmación de Simónides de Ceos (V a. C.) quien indica que "la pintura es poesía silenciosa y la poesía es pintura que habla". Sin embargo, el origen de la teoría de las relaciones interartísticas se atribuye a Horacio.

10 "El lema horaciano, ut pictura poiesis, y la idea aristotélica de que la intriga de una tragedia se asemeja a una pintura proporcionaron desde el Renacimiento hasta el siglo XVIII una constitución al sistema de las artes, constitución basada en la asimilación entre pintura y poesía" (Gabrieloni 2001-2004). La celebración de Batteux de esta concepción de las artes en Las bellas artes reducidas a un mismo principio (1746) provocó la reacción de Lessing (Laocoonte 1766) "contra el entusiasmo por la migración de cualidades y poderes, tanto estéticos como pedagógicos, entre dominios artísticos distintos" (id). Antes, Da Vinci (Paragone, fines del siglo XV) y Du Bos (Reflexiones críticas sobre la poesía y la pintura, fines del siglo XVIII) habían escrito textos relativos a la autonomía de las artes, pero ubicando a la poesía por debajo de la pintura, a diferencia de Lessing, quien aboga por el estatuto autónomo de aquella. Esta discusión es de gran interés, en la medida en que, por un lado, la pintura estaría libre de la arbitrariedad y mediación de los signos de la poesía (palabras) y, por otro, la facultad conceptual y abstracta - a fin de cuentas, filosófica y teórica- que Lessing otorga a la poesía.

11 "La pintura es poesía; siempre se escribe en verso con rimas plásticas", decía Picasso (en Standish 19). La poesía visual es otro ejemplo de esta relación que, desde el marco teórico 
La analogía entre pintura y poesía en la novela de Gil se asume como un problema para la representación del pasado a partir de documentos espurios, a la vez que como un diálogo con la antigua tradición que equiparaba ambas artes, dándoles, en cierto modo, la misma facultad representativa -con las restricciones estético-morales que advierte Horacio en nuestro epígrafe. En este caso, el narrador se toma al pie de la letra el pintar con la narración dicha época, así como el Mulato José Gil la pinta a través de colores y formas. En la novela el ejercicio de la escritura está sometido a la variación de la imagen como copia, bosquejo o boceto: así como el cuadro se ensaya y desdobla en distintas versiones, la narración constantemente se inicia en formas distintas de sí misma para exponer tal o cual acontecimiento, mostrar una escena o explicar un evento: "Y los tres pintores, entrecerrando los ojos, siguen buscando un árbol que, en el viento, se resiste al pincel con más fuerza que uno real al filo de los leñadores" (12).

\section{II.1. LA PLUMA ES AL PINCEL LO QUE LA TELA ES AL PAPEL}

El narrador observa con atención cómo el maestro Del Pozo compone el escenario de sus pinturas. Del vacío de la tela emerge una silueta, mientras dos copistas siguen los gestos del maestro, "los tres pintores hacen uno solo" (11) que, embebidos en la ficción, no reparan en el ingreso de la sirvienta que deja un jarro de vino caliente sobre el mesón, "una colina donde el viento atormenta un arbolillo. Un estúpido espino que no termina de representarse" (id). Sin embargo, "hay en la sala tres telas, y en cada una de ellas un Martínez distinto" (12). Los comentarios técnicos sobre pintura que hace Del Pozo, se convierten en poética para el narrador:

El cardenillo difiere del verdín en las siluetas. El verdegris hace un buen contorno en los volúmenes. $\mathrm{Y}$ aunque los dos colores son el mismo, debe el que toma el oficio de pintor fijar los ojos, hasta que ambos colores, que son iguales, tengan la oportunidad de ofrecer sus diferencias (10) (Cfr. 16).

¿Cuál es, entonces, la particularidad de la escritura poética?, ¿hasta dónde llegan los paralelismos?, ¿cuál es el excedente de la escritura poética, si es que 
lo hubiera?, por ejemplo, en el caso de las descripciones: "La tarde mancha el cielo en banderas. Una bandada de patos migrantes pasa alta, llamada por el norte magnético. Pero el improvisado cortejo funerario no alcanza a oír el graznido ni a vislumbrar el verde tornasol de sus plumas" (15).

En la retórica helenística existían dos figuras que nos permitirían explicar algunos de los procedimientos de la novela: la ekphrasis y la hipotiposis. La primera de ellas "se refería al intento de alcanzar por medio de la palabra la percepción visual, descripción que detenía el flujo discursivo, interrumpiendo el argumento narrativo con una excursión hacia lo espacial" (Standish 19). Esta definición considera desde el acto de "evocar imágenes visuales por medio de [1]as palabras, hasta el intento más específico que es el de usar palabras para evocar una obra de arte preexistente" (19-20). En Cosa mentale opera, con mayor énfasis, el primer significado de la ekphrasis e indirectamente el segundo, en cuanto la novela desborda la descripción de los cuadros de Gil de Castro, ya que estos son únicamente el punto de partida para evocar el mundo novelesco ${ }^{12}$. Por otro lado, la viveza de la descripción, como discurso esclarecido y coloreado (Illustris oratio), no ajustado a los regímenes de la descripción realista ("exactitud de la referencia que justifica la descripción", Barthes 149), y en la cual el poeta se involucra con el gesto vivo de la palabra, "de ningún modo en forma neutra, comprobatoria, sino colocando en la representación todo el fragor del deseo" (150), en la retórica alejandrina era llamada hipotiposis. El patetismo o emotividad de esta figura radica en que el poeta describe hechos lejanos o desconocidos al oyente como si él los hubiese presenciado o vivido ${ }^{13}$.

La escritura no solo quiere describir el cuadro, sino que pretende ser el cuadro. No obstante, solo puede aspirar a ser como el cuadro y recurrir a la facultad autorreflexiva del lenguaje para representar, tensando los marcos de verosimilitud por medio de la hipotiposis. En la novela este ejercicio retórico

12 Relativo a la segunda función de la exphrasis, en la novela opera a partir de la noción de intertexto y enciclopedia (Kristeva 1967; Eco 1979, respect.), por ejemplo, en la mención al Pequod, al “doctor" Rulfo o a Del Pozo. De tal manera, la figura de la ekphrasis se convierte en uno de los principales recursos que desestabilizan la separación ontológica entre los referentes, reales y ficticios, desestabilizando los sustratos históricos.

13 Podemos relacionar la hipotiposis con las características del discurso "mito-histórico" de la Historia de Heródoto. Lo visto y lo vivido, las capacidades visuales y auditivas, son las que certifican la experiencia del orador que estuvo en esos lugares o que se informó por boca de otros y que ahora reproduce con viveza el relato. 
establece una ruptura casi radical con el asunto del referente histórico, que, a fuerza de ser obviado o desviado en sus procedimientos de veridicción, pierde autoridad objetiva frente a la descripción recurrente, insistente y detallista que "esfuma" y "deforma" la analogía entre referente "real", referente ficticio y las correlaciones entre referencialidad histórica y referencialidad realista en la composición de la trama: "La historia se nos derrite en las manos. Siguiendo el curso de las cosas podemos llegar hasta una capilla de Renca, justo en el momento en que Gil de Castro, sin demasiada ceremonia, contrae matrimonio" (149).

Tiene lugar, como consecuencia, una tensión en la (re)producción del referente: el o los referentes que produce la novela entran en conflicto con los referentes históricos que reconocemos subyacentes al mundo representado (Pavel 171-179) -es lo que ocurre con la descripción de las manos de un O'Higgins amanerado, con el cambio de nombre a la esposa del Mulato o con la obsesión del Vaticano por saber quién fuera el confesor de Ramón Freire- porque dichos referentes no corresponden a la abstracción realista (objetiva, efectiva, sígnica) del referente histórico, en la medida en que son deformados por la paleta del narrador, cargados de referencialidad óntica, sobredescritos e ironizados por el dinamismo interno de la narración ${ }^{14}$.

La irrealidad del mundo, el "sueño del pintor" 15 como mecanismo de denuncia del mundo, plantea coartadas que hacen posible desajustar a tal punto las clavijas o los quicios del hecho causal, lineal y su narración, que integran al referente histórico en un flujo de imágenes, diluyéndolo. Como contraste y marco a estos desórdenes, el narrador señala: "Lentamente la historia se asienta. Igual que un filo. Y como el agua se va empozando. Ya lo que supimos, o pudimos saber, debe ser olvidado" (Gil, Cosa mentale 152).

14 Cito una escena que da inicio a la Cuarta parte: “-Para los que no hayan entendido nada, que será la mayoría -dice la voz del enano-, las cosas vienen más o menos del modo siguiente-subido en una pila de libros, puestos como ladrillos, el fraile enano apenas gesticula. A su alrededor los Defensores de la Cruz de Auverne, la cofradía que dirige, lo escuchan con reverencia-. Como decía, estamos viviendo tiempos de vergüenza para la Santa Madre y en ella es notoria la obra del Que Sabemos -todos se persignan abriendo mucho los ojos ante la sola mención del innombrable-. ¿A quién si no a él le conviene la confusión, la codicia, la imbecilidad reinantes? ¿A qué otro?” (167).

15 Tomo el término de Kayser, Lo grotesco, su configuración en literatura y pintura. Bs. As.: Nova, 1964. Durante el siglo XVI los italianos se referían con este término a los grotescos ornamentales y se asocia a la obra de pintores como Bosch, desarticuladores de toda lógica de lo real. 
El narrador, consciente de la mediación frente a dicho pasado, juega con las relaciones entre la representación, la referencia y la historia en tres sentidos: 1) al mostrar a esta última, de manera velada e irónica (como cambiarle el nombre a la esposa del Mulato o mostrar a un O'Higgins amanerado e incompetente), 2) al escribir la novela como si pintara, esto es, a través de procedimientos legítimos (en el sentido de que representan) pero que, dependiendo de cómo sean usados, resignifican, intervienen lo "real"16, 3) según un imperativo estético que reconoce a través de la asignación de imágenes -existencia óntica- la existencia de ese pasado como posible, plausible, efectivo (esto ocurre particularmente en el énfasis y detalle descriptivo).

\section{II.2. PinTAR EL FRISO}

La fábula de la novela transcurre en un periodo de neoclásico tardío que retoma diferidamente el diálogo entre renacimiento-manierismo y manierismobarroco, a la vez que imita y parodia estas manifestaciones del arte que en América Latina se dieron muy imbricadas al punto de indiferenciarse. Las relaciones con el Barroco no están ausentes en la novela, como la intención artística cinematográfica, la representación de sucesos que parecieran haber sido "acechados y espiados" (96) o el "carácter improvisado [que] corresponde [a una] relativa falta de claridad en la representación" (id). Por otro lado, la idea de un espacio que se va construyendo, como una entidad que depende del poeta y que es por él creada, se tematiza en la novela en la relación del adentro/afuera y queda reflejada en la analogía del narrador que observa cómo el pintor da vida al cuadro para hacer lo idéntico con la novela, instalando paisajes y escenarios, componiendo la escena como si pintara la tela: "Una pincelada de más y algo sórdido se antepondría a lo bucólico. El Peuco recortado contra el cielo basta" (20). En el taller de Del Pozo el narrador observa cómo es pintada la realidad y el modo en que se superponen los códigos estéticos sobre los códigos históricos.

La tensión entre referente ficcional y referente histórico se pierde poco a poco como efecto de los procedimientos de ruptura de planos y establecimiento de distancias y cercanías que procuran dar lugar a una imagen narrativa:

\footnotetext{
"Al fondo la infaltable rueda de gallos. Y una higuera, vieja como la injusticia. Como una primera prueba de artista, dejemos hasta aquí este aguafuerte. Ya se harán, si corresponde, las correcciones de tono y atmósfera local" (Gil 31), para describir la posada de los marinos en Valparaíso.
} 
Debemos convenir que esta estampa fugaz requiere de fondo y de lugar. Como requieren de establecimiento los dos llorosos esclavos que piscan frutas en la campiña del sur, recordando al mulatillo robando y del cual no han dado aviso al capataz de Miró, ni a nadie. Fondo falta también al notario venal. A los tahúres. A los dos duelistas muertos. A los patos migrantes (18).

Las anotaciones sobre el curso de la narración ponen en abismo el relato a partir de códigos artísticos visuales: "Es el fondo invadiendo el primer plano. La vibración de los colores en un cuadro desatento" (28). De tal manera que las coordenadas para leer la novela son las maneras de contemplar la tela como composición del cuadro: "Bástenos saber que, esbozada como telón, hay una época en apariencia apacible, de color colonial, en la que se vienen fraguando conjuras y agitaciones. [...] Todo un fondo duro, con humos de pólvora y de incendios, que una aguada liviana esconde a los ojos todavía" (18).

Durante el Manierismo, la narración pictórica renacentista se transforma -retomando indirectamente la retórica narrativa medieval de la vida de santos- y sustituye los planos o escenas que cuentan la historia por una unidad narrativa que contenga, condense y pueda mostrar los significados ya enigmados. De esta manera, el Manierismo retoma la retórica de la narración móvil, por escenas, más alegórica que simbólica; más literaria que pictórica, que es continuada por el Barroco. En cuanto a la disposición, Cosa mentale es narrada como un cuadro manierista o barroco, a través de composiciones en fragmentos, cuadros y escenas montadas, imagen descriptiva y repeticiones como variaciones temáticas ${ }^{17}$. Dichos recursos en cuanto retóricas de la imagen dejan la sensación de que la novela está constantemente haciéndose, y que, por tanto, no se trata de un objeto textual acabado. Esto es percibido en el tratamiento desigual de los motivos, las inesperadas superposiciones de escenas y el abandono de líneas de orientación, retomadas por los marcos chilena reciente, ubica a Cosa mentale dentro de la viñeta: "entendida ésta como uno de los recuadros de una serie en la que con dibujos o textos se compone una historia. Esta es sin duda la categoría más irreverente respecto de la historiografía oficial [...] burlándose de sus epistemologías y poniendo en escena los mecanismos sincréticos mediante los cuales nuestras operaciones cognitivas van apropiándose del pasado" (172). 
narrativos y paraliterarios. El cuadro, la novela, la escena teatral, son pequeños mundos, puestas en abismo de lo que ocurre "fuera".

\section{RETÓRICAS DE LA IMAGEN}

Acogiendo la hipótesis que daría origen a la novela, esto es, el criterio ut pictura poiesis realizado a través de la ekphrasis -la novela es escrita como es pintado un cuadro-, se abre la necesidad de configurar un sistema de "correspondencias" entre las artes y los procedimientos en particular, que en ningún caso pretende instalar, ni menos agotar, la presente lectura de la novela ${ }^{18}$.

Planteo, entonces, que, según un criterio analógico, es posible identificar retóricas de la imagen y de la representación en Cosa mentale a nivel narrativo, en correspondencia con la narratividad pictórica de los periodos tardíos mencionados y, con ello, el traslado o uso metonímico de algunas técnicas propias de la pintura -como el esfumado, la veladura, el claroscuro y aquellas que implican un ejercicio de montaje- a la escritura ${ }^{19}$.

18 La pregunta que plantea Standish de “¿en qué medida puede decirse que un poema, cuyo código lingüístico obliga a una lectura en serie, se acerca a un cuadro, cuyo código visual abre paso a una visión simultánea de diversas cosas?" (11-12) también ha sido subvertida en relación con los modos cómo se ha concebido tanto la pintura como la poesía. Podríamos pensar que la disparidad de los materiales o signos haría muy difícil, si no imposible, equiparar técnicas o procedimientos, la comparación por el efecto resulta interesante, pero a su vez diluye la especificidad inicial de la pregunta ¿qué es lo propio, lo particular de la poesía frente a la pintura?, por tanto, el trabajo por analogía o comparativo pareciera ser el camino más productivo, aunque muy demandante teórica, cultural y metodológicamente.

19 En el plano del análisis formal, las retóricas de la imagen en Cosa mentale se presentan a través del fragmento, la iteración y las imágenes narrativas. En cuanto al fragmento, la novela comienza con distintos episodios que quedan impresos como imágenes en la conciencia del lector, quien está comenzando a observar el friso (el duelo, el muerto, la sangre, el emblema de los dragones rojos). La narración es fragmentaria, pero en fragmentos que no son del todo autónomos y que progresivamente van configurando redes, traslados de sentido entre unos y otros. El recurso al fragmento como unidad narrativa de autonomía relativa permite, más que el relato de acontecimientos simultáneos, provocar la idea de simultaneidad en la lectura como delirio. Esto alcanza su mayor grado de intensidad en el apartado 4. Cinabrio. En cuanto a las iteraciones, estas no ocurren en el lugar de la frase -como en el caso de Hijo de mí-sino en el nivel de la narración y van modificando la lectura, en la medida en que cada vez los temas sufren una variación. La dimensión visual de la novela responde al tratamiento narrativo de la imagen, esto significa que la frase narrativo-descriptiva, soporte de la narración (Martínez 


\section{III.1. AdENTRO / AfUERA - CUADROS, ESCENAS Y FONDOS}

Uno de los principales modos de expresión de la narración a través de escenas está dado por la retórica interior-exterior "y su conveniente organización en plano de cielo y plano de tierra" (Álvarez de Araya 141) asociada a la representación de la vida de santos ${ }^{20}$. En la novela, la relación interior-exterior se tematiza en torno a una poética sobre el arte en la oposición adentro/afuera representada por el taller de Del Pozo y otros lugares relevantes.

El taller se presenta como el espacio interior, el locus de la creación y de la locura, pero también del resguardo, ya que pone entre paréntesis los avatares del mundo exterior e histórico. En el taller de Del Pozo se sintetiza y se concentra una época; allí comparecen los observadores distanciados de ese mundo, capaces de plasmarlo en la tela, sometiendo el exterior histórico a un proceso de transformación.

Pintar. Pintar. Pintar y batir los colores en los potes. Encolar las telas. Tirar con el carboncillo los esbozos. Eso es la vida del que agarra el camino de pintor. Afuera habrá estampidos y estampidas. Se rasgarán las cortinas del templo. El mundo se pondrá patas arriba. Pero aquí, pardiez, la vida viene de pintar. Y el que no lo entiende así mejor tome otra cosa, que las hay: enterrador, botero o chupador de nísperos (35).

La dicotomía del adentro/afuera también se hace patente en la posada de la Lagarta Verde, espacio de la espera de los marinos -en contraposición al

1960), se escinde y la descripción alcanza un marcado nivel de autonomía. Observamos la preeminencia de la descripción en los siguientes casos: en frases que no llegan a convertirse en narración porque carecen de verbo, en el efecto de cuadro -en el sentido que instala un marco-dado por párrafos únicamente descriptivos al final de cada apartado y en la descripción que gana lugar a la narración:

Los dos prelados se alejan por la calle mientras la luz del pleno giorno estalla por las plazas y palacios. Por esas callejas que guardan todavía el olor de las fieras en el Circo. El sonido destemplado de las espadas y tridentes de los gladiadores chocando en la arena. El rumor de viejas fiestas perfumadas de patchulí y vinos griegos. Vómitos. Axilas. El olor de la vieja Roma, con sus águilas y sus lictores (Gil, Cosa mentale 163).

$20 \quad$ Estos procedimientos "consumaron el tránsito narrativo desde lo que aconteció antes (en un lugar), hacia lo que aconteció después (en otro lugar) en la vida del santo. En efecto, el concepto de escena renacentista suponía la selección de una única escena, lo suficientemente poderosa como para evocar en la mente del espectador, lo que aconteció antes y después de la escena seleccionada" (Álvarez de Araya 141). 
constante peregrinar del Pequod o el Majestic (121)-y lugar de reposo para el narrador. Por su parte, O'Higgins debe abandonar la casa donde detentaba su cargo de Director Supremo, adornada por el monolito del ángel de la bola de oro, símbolo de poder y resguardo. Lo mismo ocurre con la estadía en la posada del Puma Rampante -lugar de espejismo e imaginación de los viajeros- cuando Del Pozo, Gil del Yugo y el Mulato cruzan la cordillera de los Andes, huyendo acusados de conspiración (119).

En este sentido, los personajes están sometidos a una constante tensión entre el adentro y el afuera: la casa, la morada, el lugar de resguardo, de la creación y de la conducción de la República. Asimismo, los personajes siempre están impulsados por una fuerza extraña-externa-que los obliga a abandonar el adentro para deambular en el afuera representado como purgatorio. En el afuera, adoptan las trazas del caminante, del peregrino errante o trotamundos, huyendo de algo o apurando el paso para estar en el adentro o encontrar un nuevo "adentro". Este afuera está representado por los caminos, el mar, las grandes vastedades -vacíos- a transitar (el camino de Santiago a Lima, de Lima a Santiago por mar y la travesía por la Cordillera).

Como hemos dicho, el "adentro", por antonomasia, será el taller de Del Pozo, pero también el taller del Mulato en la calle Catedral. Allí, Del Pozo dará indicaciones a su pupilo acerca de la condición espectral y mental de la pintura:

Vamos, vamos, que el rubito ese puede ser San Martín, dijo una voz oscura que viniendo de ninguna parte, hablaba en el estudio cada tanto. Una voz que sólo oía el mulato. Ese rubiales no vendrá nunca más por aquí, agregó la voz y se deshizo como una telaraña (89) ${ }^{21}$.

En este "adentro", el Mulato comienza a retratar los rostros de lo que sería no solo la clase dirigente chilena, sino de la aristocracia y burguesía en cierne. En su taller, el Mulato retrató la nueva cartografía del poder (Mellado 1994). Su pincel comenzó a reflejar a una sociedad ansiosa por instalar su semblante en los salones. Asimismo, la ilusión pictórica hacía posible -y verosímil- la ficción del poder, el saber y la cultura. Se trataba de una sociedad independiente, nueva y pujante reflejada en una pintura que inscribía esos rostros en fondos

$21 \quad$ Precisamente, el rubio de la pintura es el joven muerto a duelo al inicio de la novela. La imagen que tenemos de San Martín sería producto de una impostura. 
ajenos y falsos: "Y, como dice el maestro Del Pozo, lo primero en una corte es quien la pinte. Bien pintada" (61).

\section{III.2. AMBIGÜEDAD Y DOBLE SENTIDO - PERSPECTIVAS Y PLANOS}

El mundo representado en Cosa mentale nunca es como parece ser. La narración se mueve, en primera instancia, en el plano de las apariencias $\mathrm{y}$ de los indicios; el antecedente débilmente narrativo de la imagen y los acontecimientos sometidos a la capacidad o grado de conocimiento del narrador internan al lector progresivamente en el mundo novelesco. Esto ocurre de manera elocuente no por la recurrencia de los motivos del engaño, la apariencia y la incertidumbre en el transcurso de la historia o por la constante transformación de los personajes, sino por la movilidad del punto de vista de un narrador que busca verosimilitud, por ejemplo, en la incorporación del "nosotros" y del estilo indirecto libre, este último, tanto en la comparación de la perspectiva del narrador con la mirada de los pájaros (96) como en el acercamiento o distancia de la mirada, vinculada a la captación cinematográfica del teleobjetivo, entre los principales recursos.

El duelo que da inicio a la novela es un episodio de detalles, imágenes fragmentarias y referencias que describen un mundo antes que narrarlo:

$\mathrm{Al}$ amanecer dos hombres jóvenes se batieron a primera sangre en el corazón. Un leve corte de sable en el antebrazo dio fin al duelo no bien comenzara.

En el frescor de la mañana al vaho de las vacas ponía su olor, junto al del poleo, la ruda y el perfume muerto de los cueros mal curtidos (9).

Los duelistas se abrazan y avanzan en son de paz, sin embargo: "Lo que no vieron los peones fue el momento en que los jóvenes se apartan, de golpe, y comienzan un feroz esgrima [...] Tampoco vieron los camperos el momento en que el del antebrazo vendado, cruzó de lado a lado a su oponente [...] Ni vieron al del antebrazo herido correr, cubierto sólo por la casaca roja de los Dragones Reales" (9-10, énfasis mío). Esta escena se sostiene en la capacidad visual del narrador, capacidad que puede ir desde la amplitud de los paisajes hasta la precisión de los detalles. El incidente es olvidado, hasta que al final de la Primera parte (87) se hace mención al duelo, que aparentemente presenciaron las bebedoras de éter. El hecho desestabiliza a O'Higgins por tratarse de la muerte de un joven de una de las familias más importantes de 
Santiago a manos de los Dragones Reales, dato que solo conoce, a ciencia cierta, el lector -gracias al narrador-y que la familia del joven sospecha, anunciando que ha muerto producto de una síncopa.

Esta forma de exponer los hechos limitadamente, con una mirada a veces relativa, otras, panorámica, otras, detallada, hace que el conocimiento del mundo narrado sea discontinuo, aparente, anacrónico. El mejor ejemplo es la historia del Mulato, intercalada por innumerables episodios fragmentarios, que, en apariencia, la dilatan, le restan linealidad, y que incluso la convierten en una historia secundaria o que convive en el mismo nivel de las restantes: el anhelo del retorno en personajes que, cual actores, deben abandonar un escenario que se desdibuja y desaparece.

Según señalé previamente, la mirada analítica del narrador frente a los hechos se superpone a la narración misma, captando los hechos conceptualmente -más que en la progresión de una historia-a través del énfasis en la descripción y la exposición por medio de fragmentos o escenas. Sin embargo, las reiteraciones van mostrando otras capas o trazos de los personajes y de la historia: "Claro. La mala luz es buen terreno para las ilusiones ópticas" (106).

Como contrapunto a la figura del Mulato se encuentra la de Gil del Yugo, el impostor, el símbolo barroco del ser/parecer, de la máscara teatral. Sabemos que Gil del Yugo es sobrino del Gobernador del Perú en San Vicente Ferrer, que es parte del ejército español y que su apodo es Trigos Limpios. Es él quien rapta al Mulato para fines en apariencia militares, pero lo dejan en parte de pago a Del Pozo por el retrato de su querida. A territorio chileno llega convertido en Sucre, el jinete de la espuela de oro, pero también se establece en la Chimba como naturalista, para no levantar sospechas sobre su figura y paradero.

Así, poco a poco se va desbrozando la madeja y tenemos conocimiento de la conspiración del Vaticano, de la cual participa Sucre para sacar del poder a los independentistas republicanos y restablecer el orden colonial. La escena en que Sucre avanza con el Mulato por el puente Cal y Canto y el narrador no alcanza a oír lo que hablan, sugiere que toda la historia del Mulato existe en función de la conspiración para derrotar a los independentistas; desde que es raptado, dejado en el taller de Del Pozo y trasladado a Santiago como cartografista, militar y retratista oficial de la corte.

Gil del Yugo y el maestro Del Pozo instalan la ambigüedad e irrealidad del mundo. Trigos Limpios asesina al capitán del Pequod, Mr. Handless, para robar los retratos hechos por el Mulato, sobrevive al tsunami y al envenenamiento que sufre junto a Del Pozo en la pampa. Es un personaje, al parecer, libre del 
influjo del tiempo, un enigma, siempre visto oblicuamente por el narrador, pero con el cual se identifica, adoptando sus vestiduras o refiriéndose a él como si se tratara de sí mismo. Gil del Yugo solo se muestra o desvela cuando llega a su hogar en la aldea de Transmiera. Allí cae el peso y el paso del tiempo que no se dejaba sentir en los territorios fantásticos del Perú y Chile de fines de la Colonia: "Baja Gil del Yugo la vista al transponer la puerta. Esconde la mirada. Tanto ha ido ese mirar a las cosas, a los panoramas, a las gentes, que un ojo se ha quebrado" (197): es la evidencia de su mirada parcial, relativa y desgastada acerca de los hechos, equiparable a la mirada de quien narra la historia.

\section{III.3. FANTASMAGORÍAS - ESFUMADOS, VELADURAS Y CLAROSCUROS}

Los personajes de Cosa mentale, tanto históricos como ficcionales, no son un constructo sicológico, sino más bien fantasmagorías de una época ${ }^{22}$. Algunos parecen marionetas, pues son caricaturizados, sin profundidad sicológica alguna, como el Nuncio, fray Andresito, fray Gabrielli y O'Higgins ${ }^{23}$. Del Pozo bien podría corresponder a una figura esperpéntica, grotesca. Aventuramos dos motivos para hablar de los personajes como fantasmagorías: por una parte, estos adquieren una existencia ilusoria incluso dentro del mundo representado, pues el vínculo que establecen con lo "real", como mundo posible tanto ficcional como histórico, es débil, incluso si pensamos que lo "real" en una novela sea un "fundamento" débil, inestable, que pareciera no preexistir a la experiencia que los personajes hagan del mundo. En tal

22 En la novela, los personajes se presentan como fantasmagorías de la historia, bajo la idea de que todo personaje histórico que ingresa a la ficción, que se ficcionaliza, se convierte en una apariencia, fantasma, copia degradada de la historia (Cfr. Ricoeur 1998-1999). Pero son fantasmagorías no solo en relación a la historia, sino dentro del mundo narrativo mismo. "La descripción realista, dice Barthes, evita dejarse incluir en una actividad fantasmal" (150), como lo sería la hipotiposis o cualquier descripción que se aleje de la certeza referencial. Desde el punto de vista de la creación, los personajes de la novela son fantasmagorías de ese pasado, representación de figuras por medio de una ilusión óptica (RAE), mediatizada por la escritura.

23 El poeta-narrador reproduce lo que piensan, mimando su voz, pero no imita el discurrir profundo y organizado de una interioridad o una conciencia reflexiva (cosa bastante poco verosímil, pensando hoy por hoy). Este hecho -sumado a que tampoco hay una distancia objetiva o subjetiva continua por parte de la voz del poeta- hace que los personajes rocen los límites de la marioneta. Tampoco pueden ser héroes, pues no están insertos en el sistema de valores que les permitiría ser tales. 
sentido, la experiencia de los personajes configura la "realidad" del mundo y con ello la metáfora del adentro/afuera adquiere relevancia como recurrencia - constante y obsesiva- del poeta-narrador al marco (instalación de escenas, montaje de estas, necesidad de pintar el paisaje o los detalles), dirigiendo el despliegue narrativo de coordenadas espacio-temporales. Por otro lado, la condición de fantasmagorías de los personajes, en tanto personajes irreales, fluctuantes, espectrales, con una identidad característica pero no otorgada sicológicamente (sino por la caricatura, la ridiculización, la focalización externa o interna), puede asociarse a dos procedimientos pictóricos que estarían presentes en la narración, como retóricas de la imagen: la veladura y el esfumado; composición por capas, con una mezcla muy delgada, que deja zonas terminadas y otras inacabadas, y difuminación de los bordes y contornos, dando la sensación de lejanía, respectivamente.

Esta perspectiva encuentra su analogía en la pintura del Mulato José Gil cuando, dirigido por Del Pozo, retrata a la nueva clase aristocrática y dirigente como espectros de la nueva República:

Que el sueño de la razón engendra monstruos, no puede ponerse en duda. Basta con un breve paso por los interminables corredores de las Casas de Renca para entenderlo. Allí cuelgan esos sueños. Hijos de una lógica atormentada, en su conjunto dan tristeza. Uno por uno insuflan miedo y odio. Todos juntos, en cambio, producen una inquietante tristeza.

Aquella pobre familia de orates, devorados de ese mal incurable que se llama república. Res pública. Ganado embrutecido por el deseo de llevar la delantera, sobresalir, mandar a otras reses en medio de un mundo devastado [...] Una clase entera de demonios, a la cabeza de una nación de cretinos. Esa es la idea. Y todo es simétrico. Cada general es dos generales. Cada dama dos viejas putas que harían enrojecer a Mesalina (86).

Las fantasmagorías en el plano temático aluden a la existencia ilusoria e irreal de estos personajes en el pasado de la historia narrada. Esta retórica narrativa se correlaciona con lo que ocurre en la posada de la regenta Lagarta Verde, quien ve aparecer y luego desaparecer a Del Pozo, tras lo cual se persigna: “¿Quién mejor que un fantasma para pintar fantasmas? [...] ¿Quién mejor que un muerto para pintar la carne de los muertos?" (92). El teatro que despliega la novela podría ser completamente ilusorio. 
Del Pozo, el maestro loco, el Goya limeño, es enterrado frente a los ojos de sus ayudantes y de la gente de los alrededores del taller para aparecer tiempo después, como si nada hubiese ocurrido, a continuar su tela de la mujer desnuda. Sin embargo, ante la expectación, decide consultar a un médico:

En su gabinete del barrio de El Cercado, el doctor Rulfo examina larga y cuidadosamente a José Del Pozo, artista pintor sevillano, afincado de antiguo en el Perú [...]

-Sí, señor. Mi diagnóstico es que usted está completamente muerto, lo que no lo inhabilita, en absoluto, para seguir viviendo. Es algo endémico en estas regiones del mundo (184-185).

Aparte de ser un fragmento hilarante, la intervención del doctor Rulfo nos sitúa nuevamente al interior de una poética; si en Hijo de mí, Cuzco era una suerte de Comala, en Cosa mentale, el mismísimo doctor Rulfo entrega a Del Pozo su certificado de muerto-vivo. Del Pozo es arrojado del carro en medio de la cordillera, sufre los efectos de un veneno alucinógeno en la pampa, es velado y enterrado en el Cuzco, y aun así, vive, pero, sobre todo, es la voz en la conciencia del Mulato, que pinta la "galería de monstruos" de Chile:

No quiero más esperpentos de ésos que hacen tus dos soldadotes. Buenas telas egipcias de lino. Y la mejor pintura. No quiero ver tus bosquejos miserables. Que todo salga de mi mente. Así tú quedas libre para progresar en el mundo de los vivos (92).

La relación entre Del Pozo y el Mulato, a su vez, representa el sincretismo cultural de América a través, nuevamente, del taller. En él convergían criollos e indios en la elaboración de pinturas, con fines artísticos y religiosos. La pintura incesante, precisa y poseída de los indios constituía el fondo iconográfico frente al saber académico del taller:

Contra un muro de barro encalado, color de Jacinto, los indios trabajan. Cada cual tiene su propio santoral, que conoce y pinta con una levedad embrujante. Cristos sangrantes o dulces Catalinas de Siena, siempre con la mirada vuelta hacia un cielo invisible. Flores y relicarios. Natividades y descendimientos caen aquí cobrando un dulzor que sólo estos indios consiguen, porque más que con las manos, o con la mente, parecieran pintar con el candor de sus almas bajadas de la sierra. El fraile mayoral recorre el galpón y nadie nota su presencia, elevados en el éxtasis los indios pintan en un acto que es la santidad sin mácula. La luz entra por claraboyas y da lugar a 
un halo irreal, de sueño. De afuera llega un fuerte hedor a carroña, lo que no es extraño dada la proximidad de los pudrideros y basurales que circundan la ciudad en los extramuros (48-49) ${ }^{24}$.

Del Pozo sintetiza la admiración y técnica renacentista con la visión crítica y visionaria del manierismo ${ }^{25}$ y representa la idea de la imposibilidad del puro renacentismo en América. Ambos personajes muestran los cruces de visiones de mundo y técnica en estos territorios ${ }^{26}$, que están sobre la base de un dominio cultural y racial deslizado en la novela cuando el Mulato "imagina un pote blanco cayendo sobre un pote negro, para hacer un logrado tono mulato. Los potes que se quiebran con un estruendo de vidrieras y metales" (123).

\section{EL MITO DE LA INDEPENDENCIA, EL PASADO COMO ARTIFICIO}

\section{IV.1. El PASADO Y LAS IMÁGENES}

A la luz de lo que hemos revisado, el taller se configura como el cronotopo ${ }^{27}$ representativo de la novela, extensivo a las variaciones de las retóricas de la imagen realizadas en la puesta en abismo de una escritura que se impregna del exterior "histórico" y lo elabora artísticamente, según procedimientos pictóricos. Las limitaciones de una correspondencia entre modos y medios de la

$24 \quad$ En esta cita podemos ver dos características discusivas recurrentes en la novela. Por un lado, y en gran medida en la Primera parte, la presentación de Del Pozo en estilo indirecto libre. A veces el narrador le cederá la voz en algún diálogo, pero son constantes los juicios y reflexiones que podrían adjudicarse al narrador mismo. En este caso se trataría de palabras de Del Pozo, cuando comenta que "los indios pintan con el alma más que con la mente". Por otro lado, que la escena cierre con un marco descriptivo externo, sensorial, la luz y los olores que se filtran, es también recurrente a lo largo de la novela.

$25 \quad$ El taller de José Del Pozo es uno de los talleres en que se especula pudo haber estudiado José Gil de Castro, el Mulato. El otro es el de Julián Jayo, ambos en Trujillo.

26 "Desde la perspectiva global de la producción de los talleres coloniales, la pintura religiosa parece responder nítidamente a un criterio iconográfico y compositivo que remite a un gusto férreamente instituido, generando con ello la diversidad estilística entre obras producidas por un mismo taller" (Álvarez de Araya 144).

27 Cronotopo entendido como "intervinculación esencial de las relaciones temporales y espaciales asimiladas artísticamente en la literatura" (269). El cronotopo haría visible el tiempo y asimilable el espacio (series e indicios), determina el género literario y cumple una función argumental (Bajtin 1986). 
representación crean una divergencia o anacronía fundamental entre el tiempo del adentro y el tiempo exterior. En la novela es recurrente la confrontación del tiempo de los sueños, asociado al tiempo del adentro, con el tiempo del reloj, vinculado a la temporalidad histórica, social, o tiempo del calendario en Ricoeur (1998-1999): "Definitivamente el tiempo de los sueños poco tiene que ver con el acompasado tiempo mecánico de los relojes. Una vida entera puede vivirse en lo que toma la manecilla minutera en correr media esfera". Declaración de principios para una novela de escenarios móviles, donde los hechos son percibidos por el narrador como anacronías representadas de manera surreal o irracional ${ }^{28}$.

La idea de simultaneidad, como convivencia de tiempos diversos y divergentes, alcanza su punto de realización hacia el final de la novela en la fusión entre pasado y presente. Esta simultaneidad como fin del artificio narrativo para el poeta que deja de imaginar, leer o contemplar el pasado, paradójicamente evidencia una anacronía fundamental entre el pensar la obra (imaginar el pasado) y el hacer la obra (escribir la novela); la narración propiamente tal no es un trabajo del presente, sino del pasado traspuesto. El punto de vista transhistórico del narrador - que habla en medio de una anacronía- entrega un conocimiento del futuro como devenir pasado del presente de la ficción: "Un landó cerrado rueda suavemente, hacia los páramos de Renca, por un camino que hoy se habrá borrado" (77), "[el mulato] pone la sortija a su mujer en esa capilla de Renca que ya se habrá hundido también en las profundidades abisales del pasado y sus ruinas" (151). La idea de que el futuro se encuentra inscrito en el pasado funciona como artilugio para pensar o ficcionalizar un presente histórico despojado, vaciado de proyecto futuro ${ }^{29}$. El quiebre o agotamiento del efecto de suspensión temporal -buscar un presente en el pasado- indica la imposibilidad de pensar un futuro a partir del presente del

28 Momento representativo de esta desarticulación temporal, sostenida en el montaje, es la historia de Juanita Del Val y Del Pozo poseídos por una extraña fiebre, en contrapunto con el viaje en barco del Mulato y la llegada de Sucre a la ciudad de Santiago como el enigmático jinete de la espuela de oro. El montaje se transforma en un elemento central para componer este mundo onírico-pesadillesco cuando en medio de la pampa se escucha la voz del hermano Planella dando indicaciones acerca de los efectos y formas de contrarrestar los efectos de la burundanga, voz que escuchan los arrieros que encuentran a Del Pozo y Gil de Yugo perdidos en la pampa, delirando, produciéndose de esta manera una conexión inverosímil de planos, que el poeta-narrador admite como propia del mundo representado.

29 Recordemos que esta novela fue escrita en los noventa, una época brillantemente opaca. 
relato. El conocimiento artificial del pasado es un ejercicio imaginario de fascinación representativa para un presente experimentado como anacronía.

El narrador puede asumir los dichos de Del Pozo en estilo indirecto libre, pero no logra saber qué dice la carta que este recibe desde Chile, que es la antesala a su locura y suicidio: "Nunca sabremos qué dice esa carta. Ni sus consecuencias. O quizás sea lo único que llegaremos a saber, de un modo oblicuo. En esa forma extraña que tienen los cuadros de contarnos sus cuentos" (44); "sobre [la carta] un mazo de grabados con los caprichos de Goya nos impide leer su contenido" (58). El conocimiento es velado para este narrador transhistórico quien debe asumir el quiebre de las perspectivas. Por un lado, tiene conocimientos que exceden a la ficción, por otro lado, la ficción misma condiciona su conocimiento: "Hemos perdido la noción del tiempo. En mitad del vendaval tenemos no más uno que otro punto de referencia. El día del cinabrio, la llegada de una carta" (46), dirá cuando el vértigo de la narración se calme después del tsunami y de las fiebres eróticas entre Del Pozo y Juanita del Val.

En las últimas escenas de la novela, María Locadia, habitando otro tiempo, espera al Mulato niño, mientras Gil de Castro la visita para hacerle un último retrato. La impresión que le provocará el Mulato adulto será la de una fusión de tiempos que contiene una genealogía: “¿Cómo pueden en un hombre vivo, juntarse los aires de tantos hombres muertos? Mi finado esposo. Júpiter mi hermano. Mi padre, el viejo Congo, mi abuelo. Y también mi madre, en el brillo vivísimo de la pupila cuando reía. ¿Cómo pueden?" (193). La genealogía perdida de Gil de Castro reconstruida -o recordada- en el relato se contrapone a la perversión del tiempo que habita el narrador, un pasado inventado, marcado por los fracasos o traumas de un presente extraño:

Por más que buscamos y repasamos, las viejas bebedoras de éter no vuelven a mostrarse por parte alguna. Ya no están. Y la Chimba de entonces, con sus chicherías y garitos, también se nos ha esfumado, si es que alguna vez existió. En su lugar vemos frigoríficos y tranvías eléctricos que bajan traqueteando por las orillas del río. Hombres con sombrero de pita. Fábricas de hielo y curtiembres. Carros que reparten agua en sifones. Del picadero municipal no quedan rastros. El Molino Santa Magdalena ha desaparecido. El gabinete del doctor se habrá desplomado, bajo cien años de cielos repetidos. Despertamos (194). 
El narrador no ceja ante la pesadilla de la historia; soñará dentro del sueño o dentro de la pesadilla, desintegrando las contriciones de esta, reactualizando el tema del sueño dentro del sueño como lectura dentro de la lectura:

Donde estaban los mercados con sus abastos y pilastras, ahora están los rodoviarios. Donde estuvieron las menestras, hay ahora torres de cristal de cincuenta pisos. Lo que fue un día el río, es hoy una pista de alta velocidad con treinta y dos carriles. Buscamos en vano un lugar reconocible. Nada.

Donde hubo rumor menudo de hombres y mujeres, hay señales electrónicas binarias. Cifras digitales en el lugar del pregón. Por ahí la puerta de un expreso azul cobalto se abre y se cierra. Despertamos. Nos volvemos a dormir, buscando.

No es el tomo. Volumen treinta y ocho. No es el escenario. Donde hubo fábricas de hielo y cervecerías y hombres con sombreros Panamá, hay andenes de nueve niveles y el fluir incesante de una muchedumbre solitaria que sabrá dónde va, sin que lleguemos siquiera a imaginarlo. $\mathrm{Ni}$ un solo gesto nos dice aquel va de trabajo, en cambio esos otros están de paro. Volvemos a despertar (200).

El presente histórico se encuentra desprovisto de referencias para el narrador. En este contexto, la figura de O'Higgins será el epítome de la historia fagocitada por el mito; en las últimas escenas de la novela, O'Higgins delira y habla solo en la hacienda de Montalván, elaborando un nuevo proyecto de República. A O'Higgins le preocupa que la muerte esté en la memoria común que olvida, quedando solo en los retratos (189). Los objetos de la historia, sus registros, quedan apilados como ruinas del pasado en el museo. Los cuadros del Mulato, entre ellos el de O'Higgins, llegan al museo del inglés Blut, quien "recibe todo cuanto se desliza de la realidad", "un museo sin orden ni concierto, de todo lo que nunca ha sido cierto en la historia del hombre" (191). El tiempo de la historia confrontado al tiempo natural, debe sucumbir a las transformaciones, de esta manera, la esperanza para O'Higgins es el mito del retorno, que -el narrador nos lo ha dejado claro- nunca ocurrirá (176):

- ¿Me está preguntando usted si creo que nada se pierde, y que todo se transforma en otras cosas, general? -recapitula el asistente.

-Exactamente-responde, mirando hacia la oscuridad donde fermentan las levaduras y las putrefacciones hacen su trabajo, degradando, transformando, arrastrando las figuras y las materias a sus nuevos formatos--. Se huele en la noche ese reciclarse de las cosas. Ese olor a 
cambio, Peñafleta, ese olor a podrido que odiamos tanto, se responde a sí mismo el Director y bebe un largo trago de ron. El hedor de las transformaciones (200-201).

El tiempo de la Modernidad-como presente histórico imparable, inaprehensible, que "se escurre de las manos", que "hiede"-parece más fuerte que el tiempo del ensueño histórico ante la imagen. Esta fractura del tiempo en distintos planos (tiempo de la Modernidad histórica, del presente narrativo condicionado por el pasado progresivo; tiempo histórico o de los relojes y el calendario; tiempo de los sueños o de la ficción, y tiempo del mito o de la imagen) sitúa al poeta en una posición transhistórica, pero dependiente de una imaginación -una ficción- que no es garantía ni de la representación "viva" del pasado, ni del restablecimiento del mito.

El día en que el Mulato contrae matrimonio en la capilla de Renca, cuando el narrador sugiere que la capilla ha desaparecido en el futuro, también señala que se trata de "un día esfumado, como tantos, en este devenir sin retorno" (151). La superposición de tiempos y la sustitución del escenario temporal indican que el tiempo de la historia no se (r)establece, no retorna al lugar del mito como restitución del (los) origen(es). Solo restaría el artificio de la novela: "Entra a raudales Satie y la luz de la primavera. Revueltas, son una sola sensación que nos despierta, como en la infancia. El soplo de la maravilla" (203). Con estas palabras finaliza la novela. La iluminación esperada, pero construida a voluntad: la historia del presente puesta en silencio por la "maravilla" del artificio. El narrador transhistórico -su voz en abismo-adopta los rasgos del artista manierista, que aparece dentro de su propia creación, intentando mantener distancia de la reproducción del pasado hasta el fin del "sueño barroco". El pasado como artificio es el sucedáneo de la experiencia prístina, irrevocable, del presente vivido ante la imagen del pasado; frente a los cuadros del Mulato. Es también una alegoría del pasado histórico, que como respuesta a la disolución de la memoria se ancla en "momentos axiales" (Ricoeur 1998-1999) o "hitos" que señalen un camino de regreso para la imaginación narrativa.

El tiempo histórico resulta, así, un gran pretexto, un artificio montado, que contrarreste el horror hacia el presente y que exprese el escepticismo hacia el mito del pasado, como meta relato redentor, originario y fundacional. La trasposición de códigos y técnicas desde la pintura a la narración, con la consiguiente "inadecuación" o los consabidos "residuos" que supone tal procedimiento, así como la utilización de los modelos de historicidad-de la 
nación y del arte- en cuanto esquemas retóricos que producen imágenes de época, permiten al narrador mostrar que el mito de la independencia asoma tras el artificio novelesco como pulsión crítica que desajusta los relatos historiográficos nacionales.

La carga histórica sería asimilada por la obra de arte, en este caso, la pintura del Mulato, anacrónica con respecto a cualquier categoría de estilo proveniente de Europa.

\section{BIBLIOGRAFÍA}

DEL AUTOR

Gil, Antonio. Hijo de mí. Santiago: Ed. Los Andes, 1992. Cosa mentale. Santiago: Ed. Los Andes, 1994. Las playas del otro mundo. Santiago: Seix Barral, 2004.

\section{TEÓRICO-CRÍTICA}

Álvarez de Araya, Guadalupe. "Algunas fuentes compositivas de la pintura de costumbres en América Latina”. Aisthesis № 45 (2009): 137-153.

Aristóteles. Poética. Madrid: Gredos, 1974.

Bajtín, Mijail. "Formas del tiempo y del cronotopo en la novela". Problemas literarios y estéticos. La Habana: Arte y Literatura, 1986.

Barthes, Roland. "El mito, hoy”. Mitologías. México: Siglo XXI, 1981.

"El discurso de la historia". El susurro del lenguaje: más allá de la palabra y de la escritura. Trad. de C. Fernández Medra. Barcelona: Paidós, 1987.

Didi-Huberman, Georges. Ante el tiempo. Buenos Aires: Adriana Hidalgo, 2006.

Estébanez, Demetrio. Diccionario de términos literarios. Madrid: Alianza, 1999.

Gabrieloni, Ana Lía. "Interpretaciones teóricas y poéticas sobre la relación entre poesía y pintura". Saltana, Departamento de Traducción, Universidad Autónoma de Barcelona, No1, Vol. 1, 2001-2004, http://www.saltana.org/1/docar/0011.html

Guerrero, Pedro Pablo. “Antonio Gil: 'mi novela es un artilugio"'. El Mercurio, 4 de diciembre, 1994, p. 3 (suplemento).

Hauser, Arnold. Historia social de la literatura y el arte. Barcelona: Labor, 1985.

Horacio. Arte poética de Horacio. París: Imprenta Parisiense, 1867.

Hutcheon, Linda. A poetics of postmodernism. London: Routledge, 1988.

Le Goff, Jacques. Pensar la historia. 1991. Barcelona: Paidós, 2005.

El orden de la memoria. Barcelona: Paidós, 1991. 
Marchese, Angelo. Diccionario de retórica, crítica y terminología literaria. Trad. Joaquín Forradellas. Barcelona: Ariel, 1989.

Martínez, Félix. La estructura de la obra literaria. Barcelona: Ariel, 1960.

Mellado, Justo Pastor. "Informe sobre un aspecto comúnmente no considerado en la pintura: el mobiliario". La Nación, domingo 10 de julio, 1994. 34-35.

Pavel, Thomas. "Las fronteras de la ficción”. Teorías de la ficción literaria. Madrid: Arco/ Libros, 1997. 171-179.

Peter, Bürger. Teoría de la vanguardia. 1974. Barcelona: Península, 1997.

Rama, Ángel. Transculturación narrativa en América Latina. 1984. Buenos Aires: El Andariego, 2007.

Ricoeur, Paul. Tiempo y narración. México: Siglo XXI, 1998-1999.

Standish, Peter. Línea y color: desde la pintura a la poesía. Frankfurt am Main: Vervuert; Madrid: Iberoamericana, 1999.

Viu, Antonia. Imaginar el pasado, decir el presente: la novela histórica chilena (1985-2003). Santiago de Chile: RIL Editores; Universidad Adolfo Ibáñez, 2007. 